\title{
Teacher support in computer-supported lab work: bridging the gap between lab experiments and students' conceptual understanding
}

\author{
Anniken Furberg ${ }^{1}$
}

Received: 4 July 2015 / Accepted: 1 February 2016/Published online: 15 February 2016

(C) The Author(s) 2016. This article is published with open access at Springerlink.com

\begin{abstract}
This paper reports on a study of teacher support in a setting where students engaged with computer-supported collaborative learning (CSCL) in science. The empirical basis is an intervention study where secondary school students and their teacher performed a lab experiment in genetics supported by a digital learning environment. The analytical focus is on student-teacher interactions taking place in help-seeking settings during group-based activities where students analysed and reported their findings from the lab experiment. A combination of quantitative methods in the form of frequency counts of students' help requests and detailed micro-analyses of student-teacher interactions are used. The findings are that the majority of challenges faced by students concerned conceptually oriented issues and procedural challenges in the sense of how to practically solve the assignments provided to them in the digital learning environment. Most importantly, the analyses of student-teacher interactions provide insight into the considerable amount of support that is needed from the teacher to bridge the conceptual gap between the lab experiment and the students' understanding of the underlying scientific principles and procedures. The findings are discussed according to possible implications for the design of digital support tools and instruction.
\end{abstract}

Key words Teacher support $\cdot$ Computer-supported collaborative lab work $\cdot$ Help-seeking settings $\cdot$ Student challenges $\cdot$ Interaction analysis $\cdot$ Sociocultural perspective

\section{Introduction}

This paper reports on a study of teacher support in a setting where students engaged with computer-supported collaborative lab work in science. Several studies within the field of

Anniken Furberg

anniken.furberg@ils.uio.no

1 Department of Teacher Education and School Research, University of Oslo, P.O. Box 1099, N-0317 Blindern Oslo, Norway 
computer-supported collaborative learning (CSCL) and computer-assisted learning have provided valuable knowledge about various ways of supporting students' learning processes. These studies have typically analysed the support provided by various digital tools, such as simulations (Rutten et al. 2012; Smetana and Bell 2012), diagrams (Furberg et al. 2013) and graphs (White and Pea 2011). Others have scrutinized support in the form of peer collaboration (Furberg and Ludvigsen 2008; Kershner et al. 2010; Stegmann et al. 2007) or various instructional designs (Linn and Eylon 2011; Scardamalia and Bereiter 2006). The underlying claim of the current study is that more knowledge is needed about the role of teacher support in CSCL settings.

In science education, educators have traditionally used lab experiments to support students' development of conceptual understanding (Lunetta et al. 2007). Over the years, numerous digital tools and learning environments have been designed to support students' understanding of science concepts and scientific methods such as lab experiments, inquiry learning and scientific argumentation (Linn and Eylon 2011; Olympiou and Zacharia 2011). Although many studies have shown that students benefit from support provided by virtual labs and simulation tools (de Jong et al. 2013; Olympiou and Zacharia 2011), others have revealed that students struggle with testing hypotheses, connecting procedural skills with conceptual knowledge and transferring acquired conceptual understandings or inquiry skills from one setting to another (van Joolingen et al. 2007; Renken and Nunez 2013). Research in naturalistic CSCL settings has highlighted the teacher's significant role in supporting students' development of conceptual understanding (Greiffenhagen 2012; Jornet and Roth 2015; Strømme and Furberg 2015). The current study aims to further explore the role of teacher support in CSCL settings by directing the analytical attention towards student-teacher interactions in a computersupported collaborative lab-work setting.

The empirical basis is an intervention study where secondary school students and their teacher performed a lab experiment in genetics. The students' lab work was supported by a digital learning environment designed to enhance the students' reflection about the procedures and principles of DNA analysis. The analytical focus is on student-teacher interactions taking place within help-seeking settings during follow-up activities where the students processed and reported their results from the lab experiment. Help-seeking settings are settings that normally are initialised by a student's request for help, in this case directed towards a teacher, who responds in some manner (Mäkitalo-Siegl and Fischer 2011; Puustinen and Rouet 2009). The main reason for directing the analytical attention towards student-teacher interactions taking place in help-seeking settings is that these interactions display both the challenges faced by students, as well as how the teacher responds to those challenges. The present study argues for the value of adding a dialogic approach when examining help-seeking settings (Linell 2009; Mercer 2013; Säljö 2010). The study combines two complementary methodological approaches, involving categorisation and frequency counts of the students' help requests during the project and micro-analyses of selected student-teacher interactions from help-seeking settings (Hmelo-Silver 2003).

\section{Research on learning and instruction in CSCL settings in science education}

\section{Computer-supported lab work}

For several decades, educators have used lab experiments to support students' understanding of scientific phenomena and processes. According to a review of studies focusing on lab 
experiments (Hofstein and Lunetta 2003), the underlying goals of such experiments are to enhance students' development of conceptual understanding, strengthen their data-based argumentation, develop their understanding of how scientists work, as well as motivate students for learning science. Nevertheless, studies focusing on students' engagement with lab experiments have produced divergent findings. Although students often find lab experiments engaging and motivating, they may struggle with linking the procedures to the underlying scientific principles and phenomena, as well as with contextualizing and seeing the relevance of the lab experiment and linking it to their prior knowledge of a phenomena (Lunetta et al. 2007).

Several design-based studies have scrutinized how various forms of digital support tools can support students' lab- and experiment-based work in school science. Digital tools in the form of simulations and tools aimed at supporting student reflection have been in focus (de Jong 2006; de Jong et al. 2013). Starting with simulations, findings have indicated that a combination of physical lab experiments and support provided by virtual labs, often containing interactive simulation tools, can enhance students' conceptual understanding (de Jong et al. 2013; Smetana and Bell 2012). Olympiou and Zacharia (2011) documented positive effects and showed that a combination of lab experiments and virtual tools enhanced students' conceptual understanding of light and colour more than the use of lab experiments or virtual tools alone. Jaakkola and Nurmi (2008) noted similar findings in a study focusing on elementary students' understanding of current circuits in a setting that combined lab experiment and a simulation. A study undertaken by Kozma (2003) involving analyses of peer group dialogues when engaging with digital representations of chemical reactions gave some indication of why such digital representations constitute productive learning resources in CSCL settings. Kozma (2003) found that the digital representations created a shared space and opportunity for reflective reasoning by students, and also that the frequency of conceptually oriented talk was higher in student groups who were manipulating representations compared to student groups doing physical lab experiments.

Other studies have examined various forms of reflection tools, or prompts, designed to support students' reflection of undertaken experiments or inquiry activities. As is the case for the digital learning environment investigated in the current study, such tools often contain questions or sentence openers aimed at directing the students' conceptual orientation (de Jong 2006; Quintana et al. 2004). Several studies have documented that digital reflection tools serve as productive resources for students' learning processes, enhancing both their conceptual understandings and their inquiry skills (Linn and Eylon 2011). For example, White and Frederiksen (1998) showed that students who responded to reflective assessment prompts developed a higher acquisition of scientific knowledge and inquiry skills. Furthermore, especially "low-achieving" students benefitted from this type of support. Other studies have highlighted the positive effects of integrating reflection prompts with prompts that give students interpretative or experimental support in their inquiry process (Reid et al. 2003; Zhang et al. 2004). In a non-experimental study, Sandoval and Reiser (2004) focused on the effect of prompts in relation to students' reflection in peer discussion. The prompts enabled the students to perform epistemically oriented monitoring of their working process, plan activities and reflect on scientific explanations and evidence.

Along with the studies that have demonstrated positive effects of support provided by simulations and reflection prompts, other research has shown that the challenges frequently experienced by students in traditional school science settings are applicable to computersupported learning settings. For instance, recurrent findings are that students struggle with testing hypotheses, connecting procedural skills with conceptual knowledge and transferring 
acquired conceptual understandings or inquiry skills from one setting to another (van Joolingen et al. 2007; Renken and Nunez 2013). Furthermore, studies focusing on computer-supported help-seeking across various knowledge domains have indicated that students often do not take full advantage of support tools aimed at supporting their conceptual reflection (Aleven et al. 2003; Clarebout and Elen 2006; Furberg 2009).

The findings from studies examining support provided through digital support tools have offered valuable input for understanding aspects of students' learning in CSCL settings where they engage with lab work. However, despite the many positive findings related to support provided by simulations and reflection tools, results have indicated that digital support tools do not necessarily address students' conceptual challenges. In naturalistic CSCL settings, such as the one in focus in this study, students most often have access to a teacher that provides some form of support. The following section presents findings from studies focusing on the role of teacher support in computer-supported learning settings.

\section{Teacher support in computer-supported learning settings}

A review of studies focusing on help-seeking in computer-supported settings reveals that few studies have examined students' teacher-oriented help-seeking in settings with a physically present teacher (Mäkitalo-Siegl and Fischer 2011; Puustinen and Rouet 2009). One exception is a study conducted by Mäkitalo-Siegl et al. (2011). In a setting of computer-supported collaborative inquiry learning within physics, this study examined the influence of consolidation-oriented teacher support in whole-class settings. In what the authors described as a "highly structured" classroom script condition, the teacher provided instructions for consolidation at the beginning of each new inquiry phase in a plenary session. The teacher also evaluated and discussed the results with the students at the end of each inquiry phase. In the "low-structure" classroom script condition, the teacher did not interrupt small-group collaborations with instructions or provide evaluations in a plenary session. An overall finding of the study was that students' help-seeking skills were generally low and that students in both conditions tended to request executive help (i.e., ready-made answers), and asked for instrumental help (i.e., guidance aimed at understanding the solving principle) more rarely. However, students in the highly structured classroom script condition sought less help, but showed higher learning gains than students in the low-structured script condition.

Several studies have emphasized the significance of teacher-student interactions in terms of supporting students' development of conceptual understanding in computer-supported learning settings (Dolonen and Ludvigsen 2012; Jornet and Roth 2015; Mercer 2004). Mercer and his colleagues studied classroom dialogues and their functions, both in class-wide and small-group settings (cf. Mercer 2004; Mercer and Littleton 2007). By analysing student-teacher interactions, Mercer (2004) identified the following central functions of communicative teacher intervention: elicitation of students' understanding, contextualisation and re-framing of students' verbal accounts, and conceptual re-phrasing of students' utterances through the application of more scientific terms. Other studies have shown positive effects on students' development of conceptual understanding when the teacher provides indirect intervention, for instance by prompting metacognitive questions or encouraging students to retrieve sciencebased information instead of providing descriptive explanations or prompting fact-based student responses (Hakkarainen et al. 2002; Hmelo-Silver and Barrows 2008).

Studies of student-teacher dialogues have also provided insight into how digital representations such as simulations and animations can be used as resources in classroom dialogues. 
Gillen et al. (2008) demonstrated how interactive whiteboards in primary science education were used as instructional resources for facilitating students' development of conceptual understanding. In one of the study's analysed cases, a teacher used the multimodal possibilities of an interactive whiteboard to introduce the students to the phenomenon of evaporation. By using self-produced video clips and video stills to demonstrate how water evaporates in a hot frying pan, the teacher invited the students into a discussion of the process taking place. The analyses of teacher-student interactions showed that the use of multimodal presentation created continuity between lessons, established shared experience and understanding, and bridged the gap between everyday and scientific explanations of scientific principles.

Other studies have focused on the role of student-teacher interactions during inquiry-related group work in CSCL settings (Jornet and Roth 2015; Strømme and Furberg 2015). For instance, analyses of student-teacher interactions in an inquiry project about heat loss and emission of modern houses showed that the teacher-student interactions became important resources for the students to understand and take advantage of co-existing support features made available to them within the instructional setting. In other words, the teacher became the pivotal "glue" that aided students in linking and using coexisting aspects of support such as peer collaboration, digital tools, and instructional design (Strømme and Furberg 2015).

The review of the studies focusing on support provided by digital tools and teachers in computer-supported settings offers a valuable background for understanding the significance of teacher support in a setting where students engaged with computer-supported collaborative lab work in science. Seen together, the findings indicate that students' development of conceptual understanding in CSCL settings is intertwined with support provided by both digital tools and the teacher. Furthermore, engagement with digital support tools embeds possibilities for creating shared spaces for conceptually oriented dialogues between students and the teacher. This leads to the theoretical premises that form the basis for the current study.

\section{A sociocultural approach on support in CSCL settings}

From a sociocultural point of view, the notion of "helping" or supporting students in their learning processes is a central issue. This was especially highlighted in Vygotsky's (1978) concept of the "zone of proximal development," referring to the difference between what a learner can do with and without help from more experienced individuals. Vygotsky's concept reveals that help-seeking is not only desirable, but essential to the development of skills and conceptual understandings. An important part of human conduct and learning processes is the use of various material tools (Säljö 2010). These can be seen as cultural artifacts that store knowledge and social practices developed over generations (Cole 1996). This interpretation implies that digital learning environments — often containing representations such as graphs, visualization models or simulations - display and represent experts' knowledge about objects, processes or phenomena. Students interact with the knowledge and practices stored within digital learning environments when they utilize these representations in their learning activities (Säljö 2010). In this sense, digital learning environments with their embedded digital tools are resources for supporting students' development of conceptual understanding.

Seen from a sociocultural perspective, learning is a dynamic, social and interactive meaning-making process (Linell 2009; Säljö 2010). Through their interactions, participants try to interpret and make sense of situations, activities, resources in use and scientific concepts. 
Within this context, language is considered the most important tool for making sense of the world and for mediating thinking and reasoning (Vygotsky 1986), with discourse serving as a "social mode of thinking" (Mercer 2013). Making sense of scientific concepts is a dialogical matter that takes place among interacting participants in specific settings, including helpseeking settings in which students interact with teachers (Strømme and Furberg 2015).

Seeing learning as an attainment of shared meaning and understanding does not mean that students can develop just any interpretation of scientific concepts. Every scientific field encompasses a range of relevant terms and concepts, in addition to valid ways of talking about these matters. In educational settings, students perceive the teacher as an "expert" within specific knowledge domains and the main mediator of valid ways of discussing scientific concepts. The teacher is also a facilitator of prevailing valid methods of understanding assignments and solving assignments in a satisfactory manner (Jornet and Roth 2015; Strømme and Furberg 2015). Ultimately, the teacher assesses students' performances - a role of which students are very aware. Consequently, in ordinary classroom settings, students' learning processes are a matter of not only making sense of scientific concepts, but also of understanding how to respond to a set of institutional practices, values and expectations explicitly or implicitly expressed by the teacher. Seen from this perspective, help-seeking sessions provide an opportunity for students to communicate and account for their achievements and understandings and to convey their conceptual and workprocess-related challenges.

\section{The present study — research questions}

The empirical basis for the current study is a classroom setting where secondary school students and their teacher analysed and reported on findings from a lab experiment in genetics supported by the digital learning environment SCY-Lab. The present study used two complementary methodological approaches, namely categorization and frequency counts of the students' help requests and micro-analyses of selected student-teacher interactions from help-seeking settings. The following research question guided the frequency categorization of students' help requests:

RQ1: What types of help requests, in terms of focus, are raised by the students in helpseeking settings?

The second methodological approach involves micro-analyses of student-teacher interactions taking place in three selected help-seeking excerpts during group-work activities where the students processed their results from the lab experiment. The students' group-work activities were supported by designated tools within SCY-Lab. The selected student-teacher interactions are characterised by their focus on making sense of task- and conceptually related issues. The interaction analyses aim at providing a more nuanced picture of the conceptual challenges addressed by the students in help-seeking settings. Of equal importance, the interactional analysis can provide insight into how the teacher dealt with the challenges addressed by the students. The following research question guided the analyses of studentteacher interactions:

RQ2: What type of support is provided by the teacher in help-seeking settings when responding to the challenges addressed by students? 


\section{Methods}

\section{Participants and educational setting}

The data were produced during a science project about forensic medicine, which took place in 18 school lessons over the course of two weeks in October 2011. The participants were one class of 25 upper secondary school students $(N=25)$, aged 16 to 17 years, and their science teacher. The teacher began teaching science after earning his master's degree in biology and completing a one-year teacher education program at the university level in 2001. The project consisted of several sub-activities surrounding the core lab experiment in which the students performed a gel electrophoresis experiment. The empirical setting of the current study was the six lessons succeeding the lab experiment where the students processed and reported on their results from the lab experiment.

By playing the role of forensic experts, students provided possible technical evidence in the form of a DNA analysis that prosecutors could use in a trial against a new suspect in an old murder case. In the school science lab, the students performed gel electrophoresis, which is a technique that sorts DNA strands according to their lengths using electrical currents. By adding different types of DNA samples to a pre-fixed gel, students developed five distinctive DNA profiles to be compared with the profile developed from a sample found at the crime scene. In the event of a match between the crime scene sample and a suspect's DNA profile, one could assume that the suspect had been in contact with the victim. See Fig. 1 for images from the lab experiment and an example of student-developed DNA samples.

During the lab experiment, the teacher and an invited external expert who worked with gene profiling in her daily work guided the students through the meticulous work of preparing the gel displaying the five DNA profiles.

The present study focuses on the help-seeking settings encountered during the six lessons succeeding the lab experiment. In these lessons, groups of four to five students collaboratively analysed, concluded and reported their results from the lab experiment. The students' work was supported by the digital learning environment SCY-Lab, and all students had their own portable computers.
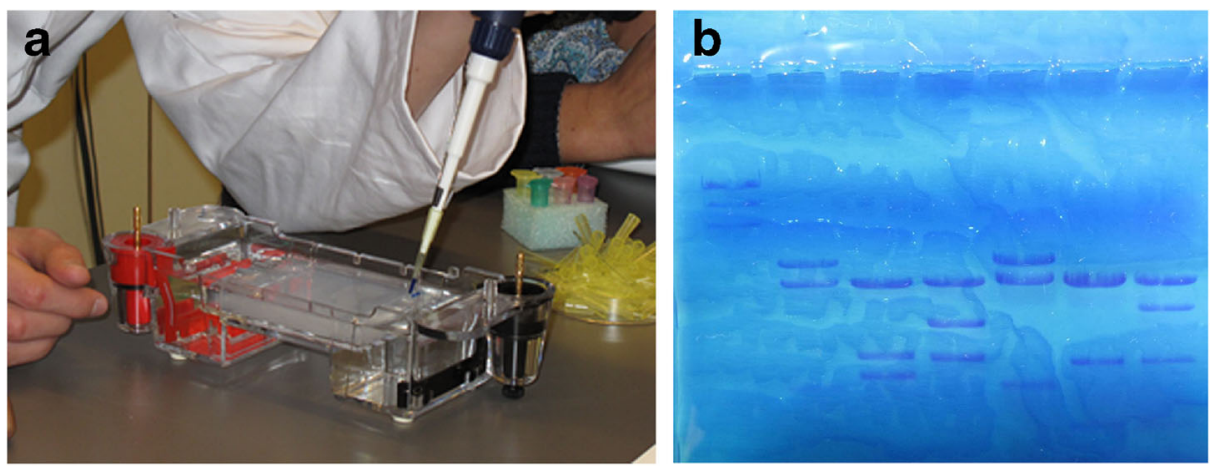

Fig. 1 a Student inserting DNA samples in the gel. b The gel product displaying DNA patterns 


\section{The SCY-lab forensic mission program}

Developers and researchers in the project Science Created by You (SCY) designed the digital learning environment SCY-Lab, which contains a variety of tools aimed at supporting students' development of conceptual understandings and inquiry skills (de Jong et al. 2012). The SCY-Lab program in the current study was the "forensic mission" designed to prompt student reflection in their process of analysing and reporting their results from the gel electrophoresis experiment described earlier. More specifically, the support tools aim at facilitating reflection on central scientific concepts and crime-scene investigations, as well as the analysis, documentation and reporting of the findings from the experiment. The SCY-Lab forensic mission is a highly structured environment featuring designated digital support tools aimed at supporting the students' inquiry tasks. Each designated support tool provides a set of specific assignments directing the students through the planning, analysis and reporting of the lab experiment. Most support tools are in the form of text-editing tools, often containing prompts such as directive questions or sentence openers presented to the students in designated writing columns. SCY-Lab also contains a set of information resources, including a handbook about forensics and DNA-related animations.

The students' work with analysing and reporting their findings from the lab experiment was supported by three designated support tools. Images of the support tools (Figs. 2, 3, and 4) are provided in the Results section alongside the analysis of the three help-seeking excerpts. The first support tool was a drawing tool enabling the students to upload and annotate digital images of the DNA profiles produced in the gel electrophoresis experiment. A second tool was a text-editing tool supporting the students' written documentation of their analysis and conclusions regarding the comparison of the DNA profiles. The third tool was also a textediting tool designed to support the students' writing of an overall concluding report in the guise of forensic experts providing technical evidence to be used in a murder trial.

\section{Data collection and analysis}

The current study is an intervention study examining the digital learning environment SCY$\mathrm{Lab}$ in a naturalistic setting. Before the intervention, the teacher had a chance to familiarize himself with SCY-Lab. The teacher played a central role in planning the practical organization of the project. Together with the researchers, the teacher developed a detailed activity plan during the week before the field trial. The teacher was not given any specific instructions regarding his role as a teacher in the student project. During the intervention, the teacher was fully responsible for implementing the instructional design without interference from the observing researchers.

The main reason for focusing on the activities following the lab experiment was that the students' attention was directed towards processing and reflecting on their experiences in the gel electrophoresis experiment. In contrast, the activities during the lab experiment were more practical with the teacher and the external expert providing demonstrations and guiding students through the meticulous work of performing the gel electrophoresis experiment. Another reason for focusing on the chosen activities was that they were group-based and supported by the SCY-Lab environment. The post-experimental phase also constituted the most conceptually dense and demanding part of the project as a whole. The succeeding activities taking place through student-teacher interactions in help-seeking settings are of especial interest because they can provide insight into the students' challenges when processing their experiences from the lab experiment and the teacher's responses to those challenges. 
The main data material applied in the present study constituted six hours of transcribed video recordings of all student-teacher interactions taking place in the post-experiment phase. A hand-held camera followed the teacher minute by minute to document the student-teacher interactions. Ethnographic field notes taken during classroom observations provided supplementary contextual data for the analyses of the participants' interactions (Derry et al. 2010). A combination of quantitative methods (frequency counts) and illustrative qualitative analyses were used to explore student-teacher interactions taking place in help-seeking settings (HmeloSilver 2003). The analysis was conducted in two steps. The first step involved coding and categorizing all help requests made by students during group-work settings. This coding allowed for an examination of the entire corpus of help requests, which enabled an identification of patterns in the students' help requests reported as frequency counts. Then, based on the coded frequency counts of students' help requests, three help-seeking excerpts were selected for interactional analytical purposes. In these help sequences, the participants' talk focused on the task or conceptually related issues. In the following sections, the two analytical approaches are accounted for in more detail.

\section{Coding of students' help requests}

In total, 70 help-seeking settings were identified in the group-work settings in which the students processed their results from the lab experiment. Help-seeking settings were typically initiated through either a verbalised question or a raised hand on the part of a student, and they typically ended when the teacher left a given group. A closer examination of the interactions taking place in the help-seeking settings showed that students often posed more than one request during a help-seeking setting. Because of these multiple requests, a total of 122 student requests were identified.

The students' help requests were coded according to their focus. The applied coding scheme was based partly on Salmon's (2000) analytical distinction between cognitive activities and social activities, which are two central aspects of students' learning-oriented activities. These two overall categories were then further divided into two sub-categories as follows: Cognitive activities were separated into object and regulative levels. Students' cognitively oriented requests were coded according to whether the requests had a conceptual focus (Con; i.e., a focus on task- and domain-specific concepts) or a cognitive regulation focus (CogReg; i.e., requests relating to task planning and how to carry out the assignments). Likewise, the socially oriented requests were coded according to the sub-categories social (Soc; i.e., a focus on the social group milieu) and regulation of social activities (SocReg; i.e., an emphasis on the regulation of the collaboration process). Technologically oriented help requests and requests about how to operate the computer or SCY-Lab were coded as technological (Tech). Requests that did not fall into any of these categories were coded as other. Janssen et al. (2007) and van Leeuwen et al. (2013) used similar coding schemes. See Table 1 for examples of the six categories. Two coders independently coded the students' help-seeking requests to allow assessment of interrater reliability; $89 \%$ of their coding was identical.

\section{Analysis of student-teacher interaction in help-seeking sequences}

Selected for detailed interactional analysis were three help-seeking settings in which the students' and teacher's attention was directed towards making sense of conceptual or taskrelated issues, in this case aspects of DNA analysis and how to respond to the assignments 
Table 1 Coding scheme for students' help request focus

\begin{tabular}{|c|c|c|}
\hline Focus & Definition & Example \\
\hline \multicolumn{3}{|l|}{ Cognitive activities } \\
\hline - Conceptual (Con) & $\begin{array}{l}\text { Requests related to task comprehension } \\
\text { and domain-specific concepts }\end{array}$ & $\begin{array}{l}\text { "Why do all individuals } \\
\text { have different DNA?" }\end{array}$ \\
\hline $\begin{array}{l}\text { - Regulation of cognitive } \\
\text { activities (CogReg) }\end{array}$ & $\begin{array}{l}\text { Requests related to task planning } \\
\text { and time management }\end{array}$ & $\begin{array}{l}\text { "Can you read through this and } \\
\text { tell us if we can move on?" }\end{array}$ \\
\hline \multicolumn{3}{|l|}{ Social activities } \\
\hline - Social (Soc) & Requests about the social group milieu & "Peter does not contribute." \\
\hline $\begin{array}{l}\text { - Regulation of social } \\
\text { activities (SocReg) }\end{array}$ & $\begin{array}{l}\text { Requests about the regulation of } \\
\text { the collaboration process }\end{array}$ & $\begin{array}{l}\text { "Is it only one of us that should } \\
\text { log in or both of us?" }\end{array}$ \\
\hline Technological issues (Tech) & $\begin{array}{l}\text { Requests about (using) the } \\
\text { program (SCY-Lab) }\end{array}$ & "How can I save this?" \\
\hline Other (Other) & $\begin{array}{l}\text { Requests that did not fall under } \\
\text { any of the other categories }\end{array}$ & "Will we get graded on this?" \\
\hline
\end{tabular}

provided in SCY-Lab. To illustrate the students' challenges with the specific learning activities and the teacher's support, one help-seeking setting was selected from each of the three postexperiment activities. These three student activities involved: 1) analysing the lab experiment results, 2) concluding the experiment and 3) reporting the findings. Each of the three activities was supported by a designated support tool in SCY-Lab.

The analysed help-seeking excerpts were selected based on three criteria. First, helpseeking settings where the student-teacher interaction focused on talking about scientific concepts and how to solve the assignments were selected. A second selection criterion was that the conceptual focus of the help requested and provided should reflect the most frequent conceptual challenges addressed in help-seeking settings. The third benchmark concerned interactional transparency, such that the help-seeking settings selected involved participants' talk characterized by a certain degree of verbal explicitness (Linell 2009; Mercer 2004). Based on these criteria, the selected settings displayed typical interactional patterns of conceptual help-seeking within this empirical setting.

The applied analytical procedure was interaction analysis, involving a sequential analysis of the talk and interaction between interlocutors (Jordan and Henderson 1995). A sequential analysis implies that each utterance in a selected excerpt is considered in relation to the previous utterance in the on-going interaction. As a result, the focus is not on the meaning of single utterances, but on how meaning is created within the exchange of utterances (Mercer 2004). This practical guideline for analysis ensures that the participants' concerns and their actual activities - not only the researchers' intentions and predefined interests - are scrutinized (Linell 2009). The video recordings were transcribed according to Jeffersonian transcription notations (Jefferson 1984). See Table 3 in Appendix for a description of the transcript notations. The discourse took place in Norwegian, and the material was translated by the researchers. The data sequences and analyses have been presented in two data analysis seminars. Critical comments and joint analysis efforts from research colleagues have strengthened the validity of the empirical analysis. In addition to the detailed examination of the interaction sequences, ethnographic information about the institutional setting was used as a background resource for understanding what was going on. 


\section{Results}

\section{Coded frequency counts of students' help requests}

During the post-experiment phase, 70 help-seeking settings occurred, generating a total of 122 help requests (see Table 2). As much as $73.8 \%$ of all help requests centred on cognitive activities. More specifically, $45.1 \%$ of all help requests concerned conceptual issues (Con; i.e., a focus on task- and domain-specific concepts), and $28.7 \%$ focused on the regulation of cognitive activities (CogReg; i.e., requests relating to task planning and how to carry out the assignments). Help requests focused on technological issues (Tech) comprised $11.5 \%$, representing a steep decline in these types of requests from the first activity to the last observed activity. Most of the technological requests concerned browser problems, abrupt breakdowns of the SCY-Lab environment, or guidance on how to open the various support tools. Only one help request concerned the regulation of social activities (SocReg; i.e., an emphasis on the regulation of the collaboration process). Help requests regarding other issues comprised $13.9 \%$ of the total; most of these requests were unrelated to the students' project or involved questions about assessment-related issues. These were also issues related to upcoming test in another subject, and when and where to meet on a planned field trip.

\section{Analyses of conceptually oriented help-seeking sequences}

In the following sections, three selected help-seeking excerpts are analysed. This part of the analysis assumes an interaction analytic form, meaning that excerpts of student-teacher interactions where the interlocutors' talk is analysed sequentially on a moment-to-moment basis. The first help-seeking excerpt was drawn from the setting in which the students analysed their findings from the gel electrophoresis experiment. In this activity, the students were asked to annotate a digitalised image of the DNA profiles they produced during the lab experiment. The second excerpt was selected from the lesson in which students documented their findings in a designated reporting tool in SCY-Lab.

Table 2 Observed frequencies (and total percentage) of student request focus

\begin{tabular}{|c|c|c|c|c|}
\hline \multirow[t]{2}{*}{ Help-seeking variable } & \multicolumn{4}{|l|}{ Inquiry activity } \\
\hline & $\begin{array}{l}\text { 1. Analysing lab } \\
\text { experiment results }\end{array}$ & $\begin{array}{l}\text { 2. Concluding lab } \\
\text { experiment }\end{array}$ & $\begin{array}{l}\text { 3. Reporting } \\
\text { findings }\end{array}$ & \\
\hline \multicolumn{5}{|l|}{ Focus } \\
\hline \multicolumn{5}{|l|}{ Cognitive activities } \\
\hline Conceptual (Con) & 12 & 14 & 29 & $55(45.1 \%)$ \\
\hline $\begin{array}{l}\text { Regulation of cognitive } \\
\text { activities (CogReg) }\end{array}$ & 9 & 10 & 16 & $35(28.7 \%)$ \\
\hline \multicolumn{5}{|l|}{ Social activities } \\
\hline Social (Soc) & 0 & 0 & 0 & $0(0 \%)$ \\
\hline $\begin{array}{l}\text { Regulation of social } \\
\text { activities (SocReg) }\end{array}$ & 1 & 0 & 0 & $1(0.8 \%)$ \\
\hline Technological (Tech) & 9 & 4 & 1 & $14(11.5 \%)$ \\
\hline Other & 2 & 10 & 5 & $17(13.9 \%)$ \\
\hline Total & 33 & 38 & 51 & 122 \\
\hline
\end{tabular}


Here, the students were assigned to provide a detailed account of their conclusions based on their analysis of the DNA profiles. The final excerpt was drawn from the setting in which the students were to write down their findings in a final report. All three analysis sections have similar structures. Each excerpt is followed by a sequential analysis of the interaction with a two-fold focus on 1) the various challenges addressed by the students and 2) the teacher's responses. Each analytical section concludes with a paragraph emphasising the most important aspects of the students' challenges and the teacher's support.

\section{Activity 1: Analysing lab results}

The day after the gel electrophoresis experiment, the students returned to their classroom to process their lab results in SCY-Lab. At the end of the previous lab session, the teacher photographed each student group's gel and uploaded the images to a shared online workspace. Before the groups began their work in SCY-Lab, the teacher summoned them for a 20-min plenum session. He displayed one group's DNA profile image on the digital whiteboard (see Fig. 1b). The teacher then recapped the experiment by quickly repeating what they did in the different phases of the electrophoresis experiment. He focused on how the amplified enzyme cut the DNA strand into fragments of various sizes and how the power provided by the electrophoresis apparatus caused the smallest DNA fragments to move farther away from the wells than the larger ones. After this recap, the teacher turned the attention to the new activity, which was to annotate and compare the various DNA patterns appearing on the image of the gel produced in the lab experiment. He directed the students' attention to the differently sized bands in each DNA profile and asked the students to compare the band patterns, prompting them to suggest whether any of the DNA profiles matched. Several of the students suggested that DNA profiles 2 and 5 matched. The teacher confirmed this response and then provided positive feedback to the whole class. After a short demonstration of how to upload the gel images in SCY-Lab, the teacher instructed the students to begin their group work.

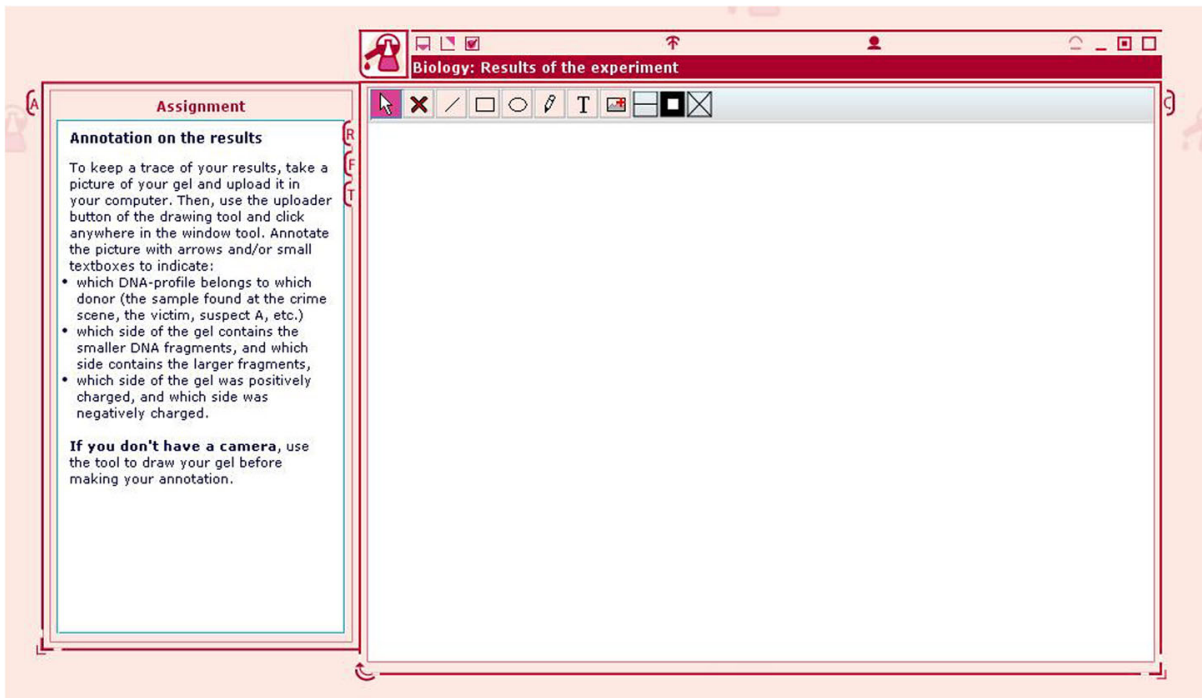

Fig. 2 Designated tool supporting the students' annotation of the DNA profile image 
The students' first step in processing the results from the electrophoresis experiment was to analyse the images displaying the DNA profiles. The students were to annotate the uploaded images of their DNA profiles using the designated support tool in SCY-Lab (See Fig. 2).

The assignment presented in the support tool directs the students' attention to specific features of the DNA profiles by instructing them to a) indicate the originator of each DNA profile (e.g., Suspect $1,2,3$, etc.), b) determine which side of the gel contained the smallest and longest DNA fragments and c) determine which sides of the gel were positively and negatively charged.

Excerpt 1 is from a help-seeking sequence that took place during the activity in which students analysed their results from the gel electrophoresis experiment. Here, Andy, Eric and Finn summon the teacher for assistance. The students have uploaded their DNA profile image to the designated SCY-tool, but then encountered problems understanding what to do

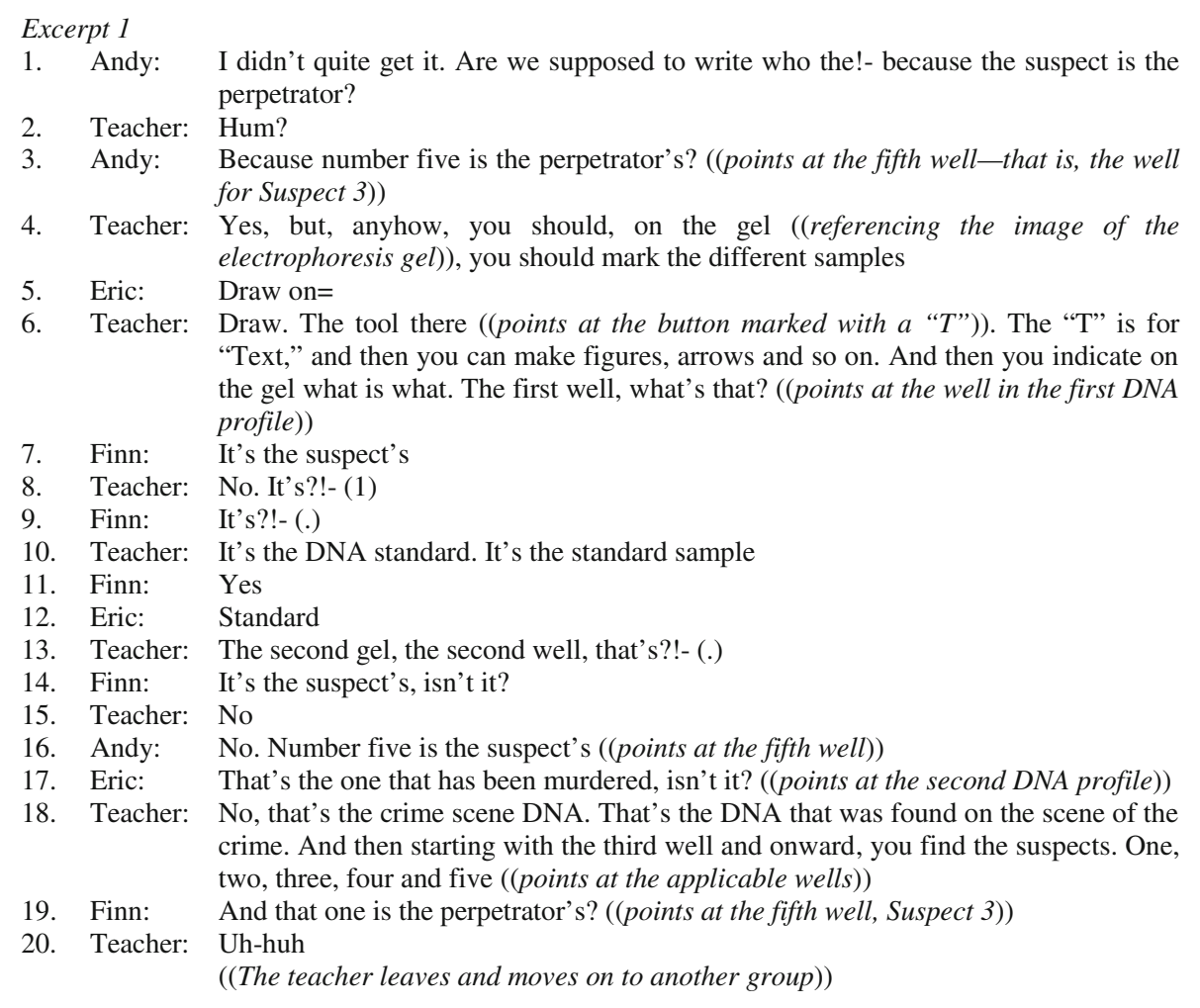

The interaction taking place in Excerpt 1 shows that the students experienced several challenges during the first step of processing their results from the lab experiment. A major challenge concerned making sense of the representation of the DNA profiles. Andy expresses this challenge in the opening of the excerpt, where he wants the teacher to confirm the suggestion that DNA profile "number five" belongs to the "perpetrator" (line 3). Even though Andy identifies the correct matching DNA profile ("number five"), he seems to be unaware that the correct denotation of DNA profile "number five" is "Suspect 3." The same challenge is also seen in lines 6 through 14 , in which the students mix up the denotations of the DNA profiles when the teacher asks them to name the originator of each profile. The problem here is 
that they do not take into account that the DNA profile image contains seven profiles. The first image represents the standard sample, the second represents the crime scene sample and the last five are DNA profiles developed from samples from the five suspects. Another challenge concerns how to make sense of the assignment presented to them by the designated support tool in SCY-Lab. Andy first addresses this challenge in his initial request to the teacher (line 1) telling him that they do not quite understand what they are supposed to do. The teacher explains that they should mark their uploaded image by using the drawing tools in SCY-Lab and then demonstrates some of the functions in the annotation tool (line 6).

Examining how the teacher responds to the students' challenges reveals that the teacher provides different types of support. One type involves helping the students structure their work process, as seen in lines 4 and 6 when the teacher prompts the students to annotate the gel images before writing down their conclusions regarding a possible match. By annotating the image first, the students will gain a starting point for their written analysis. The teacher also provides support in the form of guiding the students in how to practically annotate their up-loaded image by demonstrating how to use the various drawing functions in the annotation tool in SCY-Lab. Most importantly, the excerpt shows that the teacher provides support by eliciting the students' understanding of the DNA profile representation. As seen in the excerpt, the teacher begins with an eliciting strategy which involves prompting cued questions. For example, in line 6, the teacher asks for the correct denotation of the first of the seven DNA profiles (the DNA-standard sample). Finn incorrectly suggests that the sample belongs to the suspect. When Finn fails to come up with the correct denotation when prompted for the second time, the teacher provides the correct answer. Once more (line 13), the teacher tries out the cued question strategy, this time by asking for the denotation of the second DNA profile (the crime scene sample). Again, Finn incorrectly suggests that this would be the suspect's DNA profile. The teacher rejects Finn's suggestion, and this time Andy states that sample number five represents the suspect. Eric interjects by suggesting that the second DNA profile is from the victim. Realising that the students are experiencing major challenges in understanding the DNA representation, the teacher changes his eliciting strategy of prompting cued questions. Instead, he chooses to explain the denotations of the DNA profiles himself. As seen in line 19, after the teacher's explanatory account, Finn correctly identifies the DNA profile belonging to the "perpetrator".

Summing up, the analysis of the student-teacher interaction taking place in Excerpt 1 illustrates some of the most frequent challenges addressed by students in the activity of analysing their results from the lab experiment: They grappled with making sense of the assignments in SCY-Lab, understanding how to perform the task and interpreting the DNA profile representations. The analysed excerpt shows that the teacher provided help through structuring the students' work process, demonstrating how to use the annotation tool in SCYLab and guiding the students' conceptual understanding of how to interpret the DNA profile image. Most importantly, the analysis shows that the teacher adjusted his eliciting strategy: When facing the students' major conceptual challenges, he went from prompting cued questions to providing explanations of the conceptual issue confounding the students.

\section{Activity 2: Concluding the lab experiment}

The second activity in the post-experiment phase was to conclude the lab experiment based on a comparison between the DNA profiles represented in the gel image. Two lessons were dedicated to this activity. The students were to write their accounts in a text-editing column in the designated support tool (see Fig. 3). 
The text-editing column, as seen in Fig. 3, contained three topical sentence openers instructing the students to a) analyse their results, b) compare their results with other groups and c) draw a final conclusion.

Excerpt 2 is from a help-seeking sequence where Tina and her group have finished annotating their DNA profile and have started writing down their analysis. The annotated image of the DNA profile suggests that they have correctly figured out a match between two the DNA profiles. While Tina is conversing with the teacher, the other students in her group are paying attention to the conversation. In front of them, the students have one computer showing the designated SCY-Lab tool and a second computer displaying the image of their DNA profile

\section{Excerpt 2:}

1. Teacher: Let's see, what do you want to know?

2. Tina: I was wondering what these are called ((points at the horizontal lines in one of the DNA profiles)). Are they fragments?

3. Teacher: Each little band is a fragment ((points at the DNA profile image on the laptop))

4. Tina: ((points at the DNA profile image on the laptop)) But all of them, then?

5. Teacher: That's a profile. (.) All these bands are called a DNA profile

6. Tina: A DNA profile. ((looks at the teacher)) So we can write that, through observation in the experiment, we have determined that the crime scene DNA profile (2) shows similarity with the DNA profile of Suspect 3

7. Teacher: Yes

8. Tina: And then!- (2) ((looks at the image)) because of the fragments, we can see that there are two fragments on the first one, the crime scene, which can be compared with that one ((points at Suspect 3's profile)). On the other one, it's possible to see four fragments here ((points at Suspect l's profile))

9. Teacher: Uh-huh

10. Tina: And three fragments here (2) ((points at Suspect 5's profile))

11. Teacher: Uhum. That have travelled differently

12. Tina: ((looks at the teacher)) That have travelled differently

13. Teacher: Uh-huh

14. Tina: Yes. So then we can!- but wasn't it something about dark and bright stuff and (.) Is it?

15. Teacher: No, that's not that important

16. Tina: Okay, so that's the only reason, right? So we can't analyse more than that?

17. Teacher: No

The interaction taking place in Excerpt 2 shows that the students, here represented by Tina, experience some challenges when they are to conclude their findings from the lab experiment. Like the previous group, these students grapple with making sense of the representation of the DNA profiles. However, the focus of the difficulty has changed: the students in this group struggle with finding the correct terms for the various components within a DNA profile. This is seen in line 2, where Tina wants the teacher to confirm that the horizontal lines in a DNA profile are called "fragments". She also wants the teacher to tell her the correct term for all of the fragments appearing in a vertical line, and the teacher explains that the vertical bands represent a "DNA profile".

A second challenge addressed in Excerpt 2 concerns how to formulate a written scientific account of the analysis and conclusion. Tina first addresses this challenge in line 6 , where she suggests a way of formulating a written account of their identified match between two DNA profiles. This is also seen in line 8 , where she accounts for 


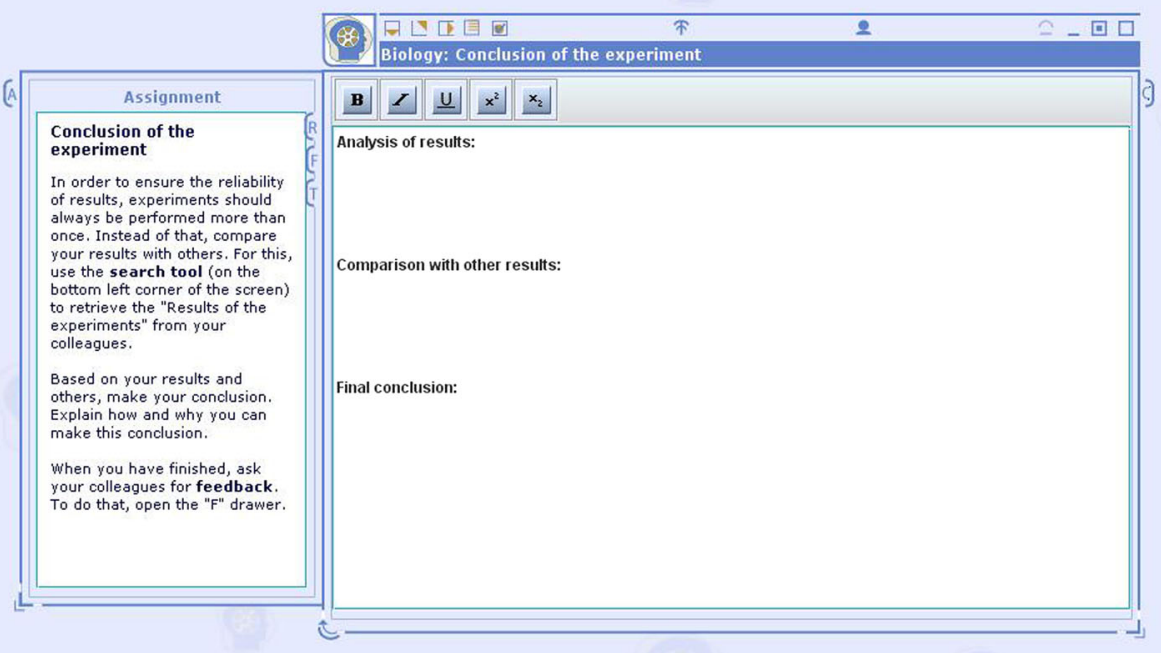

Fig. 3 Designated tool supporting students' lab experiment conclusion

features in the two matching DNA profiles. An interesting aspect of Tina's requests is that she does not simply ask the teacher to tell them what to write. By opening her request using the inferential cues "so" (line 6) and "and then" (line 8), Tina signals that she understands and makes use of the teacher's previous responses. The notable pause after Tina's inferential cue "and then" and her intense way of studying the DNA image and talking without looking at the teacher, then looking up at the teacher when she finishes her account, gives the impression that she wants the teacher's response to her reasoning (lines 8-12).

Shifting the analytical focus, the student-teacher interaction shows that the teacher provides various types of support. First of all, the teacher provides support by validating the students' suggestions. The teacher confirms Tina's suggested denotation for the fragments (line 3), her suggestion for how to write up a written account (line 7) and her suggestion for how to perform the DNA profile analysis (line 9). The teacher also offers support by guiding the students' conceptual attention. Line 11 is one example, where the teacher prolongs Tina's account about the fragments by adding "that have travelled differently". By continuing Tina's utterance and emphasising the word "travelled", the teacher directs Tina's conceptual attention towards a central scientific principle of the gel electrophoresis method; the differences in the movements of smaller and larger DNA fragments when exposed to the electrophoresis. Another example of how the teacher directs the students' conceptual attention is displayed in his response to Tina's question about the relevance of "the dark and the bright stuff" (line 14). In line 15, the teacher directs the students' conceptual attention away from what he sees as less relevant issues.

In summary, the analysis of Excerpt 2 revealed that students struggled to make sense of the representation of the DNA profiles and formulate their written accounts of their DNA profile analysis. The latter challenge seemed to be related to the students' lack of appropriate terms to be used for their analysis. The teacher provided 
important support by validating students' suggestions and guiding their conceptual attention. This involved directing the students' conceptual attention towards what the teacher considered to be especially pertinent, such as the movement of DNA fragments, and away from less relevant issues.

\section{Activity 3: Reporting findings}

In the final activity, the students were to present their findings in an "official report" addressed to the fictive general attorney, which would be used as the evidential foundation for a court trial. The main intention behind the assignment and the designated support tool was to help students contextualize and see the relevance of the undertaken gel electrophoresis experiment. As forensic experts, the students were instructed to confine themselves to unbiased observations and reliable conclusions. To write the report, the students needed to incorporate the contextual and scientific information both provided and retrieved during the pre-experimental phase. The students were asked to write their report in the designated support tool in SCY-Lab (see Fig. 4).

This tool consisted of an embedded text-editing tool, which provided prompts using topical headlines and sentence openers addressing essential issues that the students were expected to address. These issues included accounting for the crime case facts, the collected biological material and the applied DNA analysis method, as well as providing a justified conclusion for the DNA analysis. Two school lessons were dedicated to the reporting activity. In Excerpt 3, Ali and John have just started their work with the official report, while the two other students in their group finalize their work with the previous assignment. Struggling with understanding some of the

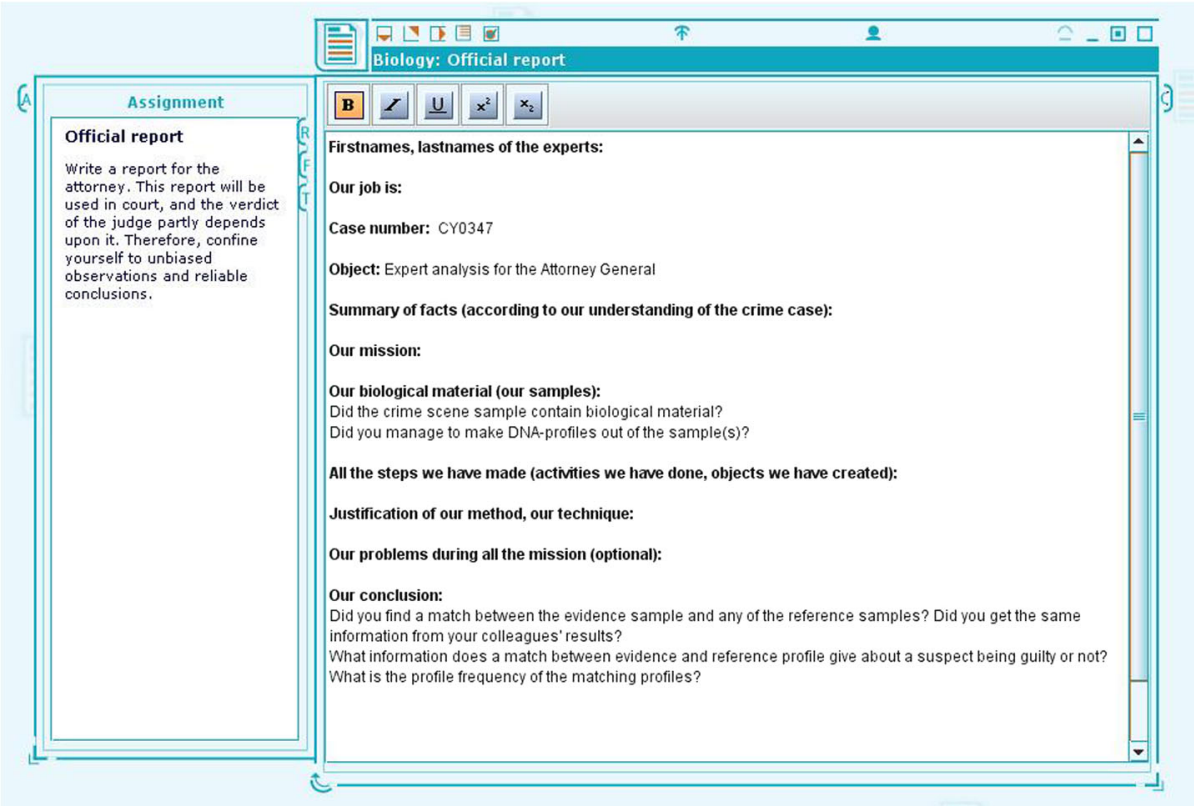

Fig. 4 Designated tool supporting students' writing of a report 
elements in the assignment presented in SCY-Lab, Ali and John summon the teacher to ask him to elaborate on one of the presented guiding questions.

\section{Excerpt 3:}

1. Ali: ((reads from the screen $))$ What information=

2. Teacher: does a match between one of the suspects and the crime scene give? What type of information does that give? Specifically speaking

3. Ali: That he has been at the crime scene

4. Teacher: Yes, right. That he's been= and in this case, if you read ((points at the digital whiteboard displaying a fictional news article about the case)). Where did they find the DNA traces?

5. Ali: ((reads the news article)) Under a woman's fingernail

6. Teacher: Yes

7. Ali: $\quad$ Oh, oh, oh. So that means that the woman resisted?

8. Teacher: Yes, and you know that he has been near her shortly before she was hurt, right?

9. John: So, that point says!- or if we are to answer that, we simply say that the person we have DNA from, or the DNA profile that matches the crime scene, specifically indicates that that person was close to the woman before she died?

10. Teacher: Uh-huh. Shortly before she died

11. ((John starts typing on his computer $)$ )

12. Teacher: Why shortly before? What happens with biological material over time, do you remember? Seen in relation to the first assignment, where you were to list some points on how to preserve biological material

13. Ali: By cooling

14. Teacher: By cooling, yes. Why?

15. Ali: Because then!- (.) a type of enzyme is held, likes to be kept cool

16. Teacher: Not only enzymes, because what happens with DNA if you store it at room temperature? Or, what happens with biological material after a short while if you store it at room temperature?

17. Ali: It gets contaminated

18. Teacher: Uh-huh, it gets (.) All the bacteria break it down very fast, right. That's why you need to store it cool and airtight, right. What happens with biological material under a nail over time? What do we have on=

19. Ali: It gets covered

20. Teacher: It's not only covered; it disappears, and it gets destroyed, right?

21. Ali: So, that implies that the police found the evidence rather soon, really?

22. Teacher: Uh-huh

23. Ali: Then we know what to write

((The teacher leaves))

The most interesting aspect of this interaction is that it illustrates how the teacher provides support in several ways. In the opening of the excerpt (line 1), the students initially summon the teacher asking for help in understanding the assignment. The teacher responds by reformulating the assignment question (line 2). When reformulating, the teacher replaces the scientific terms "evidence" and "reference profile" with more everyday concepts. As seen in line 3, this reformulation allows Ali to develop a reasonable suggestion for an answer. The teacher also provides support by offering guidance in finding relevant information. In line 4, the teacher asks where the DNA traces were found and directs the students' attention towards a relevant news article. After some reading, Ali states that the DNA traces were found under the victim's fingernails, before eagerly inferring that this means that the woman resisted when she was attacked (lines 5 and 7).

A third type of support the teacher provides is to elicit and guide the students' conceptual understanding. By alternating between posing cued questions and adding elaborations, the 
teacher leads the students' attention towards relevant details (see lines 2, 4, 8, 12, 16, 18 and 20). An example of this strategy can be found in the teacher's response to Ali's point about the woman resisting her attack (line 8). In addition to confirming Ali's suggestion, the teacher adds that they can infer that the perpetrator was in physical contact with the victim "shortly" before she died. After noticing that John fails to pick up on the additional information, either verbally (line 9) or in his typed response in SCY-Lab (line 11), the teacher repeats his attempt to direct the students' attention (line 12). The strategy continues all the way through Excerpt 3, via the discussion of cooling (lines 13 to 18) and decomposition of biological material (lines 18-22), until the students finally state that they know what to do (line 23).

Finally, the teacher offers support in contextualizing the undertaken lab experiment. A comparison of the analyses of the three excerpts makes it possible to identify cumulative changes in the orientation of the student-teacher interactions. In the first two settings, the student-teacher interactions focused mainly on highly specific issues, such as the components of a DNA profile or the procedures of a DNA profile analysis. In the setting in which the students were to report their findings to a "third party", the teacher's method of posing cued questions directed the students' attention towards more general scientific aspects of DNA analyses. Put slightly differently, the teacher used the help-seeking sessions as situational opportunities for applying conceptual guidance drawn from the specific context of DNA analysis to the more general context of the relevance of DNA analysis in forensic settings.

Summing up, the analysis of Excerpt 3 shows that the students struggled to make sense of the assignment and to identify relevant information. The teacher addressed the students' challenges by reformulating the assignment, by guiding them on where to find relevant information and by directing their conceptual attention through prompting cued questions and providing elaborations. As shown by the analyses of the two previous excerpts, the teacher tried the eliciting strategy of prompting cued questions without much success. Upon realizing that the cued question strategy did not provide sufficient support, the teacher provided detailed explanations about the conceptual issues raised by the students. In the setting presented in Excerpt 3, however, the teacher was more successful in using the cued question eliciting strategy. In this setting, his way of prompting cued questions enabled the students to participate in shared reasoning and to contextualize and see the relevance of the undertaken DNA-analysis experiment.

\section{Discussion}

To understand the students' challenges when processing their experiences from the lab experiment and how the teacher dealt with the students' challenges, the current study combined a quantitative method (i.e., frequency counts of help requests) with detailed microanalyses of selected student-teacher interactions taking place in help-seeking settings (HmeloSilver 2003). The frequency coding showed that the students' help quests primarily concerned conceptual issues and procedural regulation issues. Of the 122 help requests made by students, $45.1 \%$ concerned conceptual issues (Con), and $28.7 \%$ addressed procedural aspects, such as task planning and how to carry out the assignments (CogReg). Furthermore, the analysis showed a nearly complete absence of help requests in the area of regulation of social activities, indicating students did not seek help with peer collaboration or task division. This finding is consistent with a previous study of teacher support provided in an online learning environment, which found that few teacher interventions focused on regulating social activities, such as collaboration processes (van Leeuwen et al. 2013). Concerning the current study, one 
explanation might be that the assignments in SCY-Lab were designed in such a manner leaving little room for open inquiry and divergent approaches towards solving the assignments.

The micro-analyses offered a more nuanced picture of the students' challenges and the teacher's responses in help-seeking settings. The students primarily faced conceptual and procedural challenges. Regarding conceptual challenges, the analyses revealed that students found it difficult to link the underlying scientific principles of the electrophoresis method to the practical procedures performed in the lab experiment. They also struggled to link the scientific principles to the digital representation of the DNA profiles. Another conceptual challenge was that students lacked the appropriate terms for the various components of a DNA profile, making it difficult for them to write up their analysis. Concerning procedural challenges, the students experienced major challenges understanding the practicality of performing a DNAprofile analysis and writing a scientific account. The latter challenge seemed to be closely related to the students' lack of appropriate terms.

The analyses of the teacher's responses showed that the teacher provided both conceptual and procedural support. The interaction analysis revealed the teacher initially tried to make use of an eliciting strategy involving prompting cued questions. Upon realising that this strategy did not provide enough support for the students to engage in an evolving conceptually oriented dialogue, the teacher adjusted his strategy. In the first two activities, he eventually provided the requested information himself and thereby enabled the students to carry on their work. In the third activity setting, the teacher had more success with the cued question approach because the students were asked to provide a less technical and more "everyday" account of their conclusions.

As shown in the literature review, several studies have reported positive findings in supporting students' conceptual understanding of lab experiments and inquiry-based learning through digital support tools (de Jong et al. 2013; Olympiou and Zacharia 2011). However, research on students' learning in lab-work settings, including computer-supported lab settings, have shown that linking the practical lab work to a conceptual understanding of the underlying scientific principles and procedures is challenging for students (van Joolingen et al. 2007; Lunetta et al. 2007; Renken and Nunez 2013). Studies focusing on teacher support in computer-supported settings have shown that such support is pivotal (Gillen et al. 2008; Mäkitalo-Siegl and Fischer 2011; Strømme and Furberg 2015). The empirical findings of the current study are in line with and supplement findings from previous research showing that students struggle to link their experiences with practical lab work to an understanding of scientific principles, concepts and procedures. Furthermore, the detailed analyses of the dialogues taking place within help-seeking settings have provided insight into the various aspects of students' conceptual challenges, as well as the form and significance of the teacher's help. Based on previous research and these empirical findings, the following sections will discuss possible implications for designing digital support tools and instruction aimed at supporting students' reflection on lab experiments.

\section{Implications for the design of digital support}

Design studies focusing on support provided by digital tools intended to enhance students' reflection of science concepts and the process of inquiry have documented positive effects in the form of gains in inquiry skills and conceptual understanding (de Jong 2006; White and Frederiksen 1998). Other studies have highlighted the positive effects of integrating reflection prompts with support tools providing interpretative or experimental support in their inquiry 
process (Reid et al. 2003; Zhang et al. 2004). The support tools in SCY-Lab were designed to support students' reflection in their process of analysing and reporting their results from the gel electrophoresis experiment. As the analyses clearly showed, the SCY-Lab support tools with their embedded instructive assignments did not provide enough support for students to link the practical procedures conducted in the lab experiment with the resulting reflection assignments. Neither did the digital tools provide sufficient support for them to understand the underlying scientific principles of developing DNA profiles. In turn, it was difficult for them to make sense of the digital representation of the DNA profile. The analyses revealed that students needed extensive teacher support to bridge the conceptual gap between the lab experiment and the SCY-Lab reflection assignments.

Several studies have reported positive findings of students' engagement with virtual labs and experiment-related simulation tools (de Jong et al. 2013; Rutten et al. 2012; Smetana and Bell 2012). Furthermore, studies have found that combining physical lab experiments with digital simulations tools enabling students to go through the experiment before, during or after the physical experiment outperform both lab experiments and virtual experiments (Olympiou and Zacharia 2011). Regarding the current study, a digital representation (e.g., an interactive gel electrophoresis simulation) might have provided additional support to allow students to bridge the aforementioned conceptual gap. Such interactive digital representations may create spaces for conceptually oriented peer dialogues and for shared reflective reasoning by students (Furberg et al. 2013; Kozma 2003). Furthermore, additional digital support could have been provided by attention cuing, or devices that direct the students' attention towards specific features of visualizing representations (Kluge 2014; de Koning et al. 2009). This could be especially relevant for supporting the students' DNA profiling, which involves comparing and contrasting specific features of unique DNA profiles.

Findings from previous studies reporting on more challenging aspects of students' computer-supported learning have revealed that support from digital support tools or learning environments often is not sufficient for students to develop robust understandings of conceptual issues. Combing such information with the empirical findings of the current study can provide valuable input for discussing possible instructional implications, especially implications in the form of teacher support.

\section{Implications for instructional design}

Previous studies have shown the value of student-teacher dialogues where support is provided through open-ended and meta-cognitive questions (Hakkarainen et al. 2002; Hmelo-Silver and Barrows 2008). Furthermore, studies of student-teacher interactions have shown that the teacher in both whole-class and group-based settings provides conceptual support by eliciting students' understanding through cued questions, contextualisation and re-framing of students' conceptual accounts and re-phrasing of students' utterances through the application of more scientific terms (Mercer 2004; Mercer and Littleton 2007). Mäkitalo-Siegl et al. (2011) investigated the significance of consolidation-oriented dialogues in an inquiry-oriented CSCL setting and determined that students sought less help but showed higher learning gains when the teacher provided consolidation instructions in the form of introductions to new tasks, evaluations and discussions of results in plenary sessions.

In this study's empirical setting, most of the time was allocated to group-work activities, so most student-teacher interactions took place within help-seeking settings during such activities as the teacher moved among the peer groups. The pre-designed implementation plan (a joint 
effort by researchers and the teacher) left relatively little time for whole-class activities. However, as illustrated by the ethnographic description preceding Excerpt 1, the teacher organized short whole-class settings during which he went through the activity of the day or demonstrated the SCY-Lab support tools. Based on findings from previous studies documenting the productive aspects of teacher-led whole-class dialogues and dialogues intended to consolidate conceptual and procedural aspects of student work, a reasonable instructional implication is that teacher-led whole-class dialogues could have been used in a more extensive and systematic way. For instance, using the challenges addressed in the helpseeking settings as a point of departure, the teacher could identify frequently raised challenges and discuss these matters at some point during each of the three activities.

The previous section discussed the potential benefits of combining digital representation tools (e.g., simulations) with reflection tools to bridge the conceptual gap between the lab experiments and the SCY-Lab reflection assignments. Digital representations visualizing scientific concepts can also be productive resources in teacher-led classroom discussion, as Gillen and colleagues demonstrated in their study of interactive and multimodal whiteboards used in primary science education (Gillen et al. 2008; Kershner et al. 2010). In the current study, the teacher used a digital representation of the DNA profiles produced by the students during the lab experiment as a resource when recapping the lab experiment. In contrast to the study by Gillen et al. (2008), this digital representation showed only the end product of the students' work, and not the process of developing the DNA profiles through gel electrophoresis. The findings from previous studies, which have indicated numerous benefits of such representations (e.g., establishing shared understanding and bridging the gap between everyday and scientific explanations), suggest that a simulation, animation, or sequence of still images displaying the process would have been a valuable resource in creating shared spaces for conceptual reasoning.

A final reflection regarding the instructional design concerns the organisation of practical lab experiments. Traditionally, lab experiments are often organised in a sequential manner, implying that the experiment procedures are introduced to students in a stepwise manner with few possibilities of contextualizing and reflecting on the meaning of the undertaken procedures. The sequential organisation of lab experiments might be one of the reasons that students often find it challenging to see the underlying scientific principles and relevance of the undertaken experiments (Kozma 2003; Lunetta et al. 2007). On a general basis, but also of relevance for the conducted lab experiment in the current study, providing enough time for reflection-oriented group- and whole class dialogues during practical experiments is of vital importance. According to Vygotsky, the juxtaposition of performing and talking is at the very core of human development, whereas language is considered the most important tool for making sense of the world and for mediating thinking and reasoning (Vygotsky 1986). Also of relevance here is the importance of creating dialogic settings where students are prompted to explicate their understandings, and perhaps even more important; what they struggle to understand. Such explications constitute what can be seen as dialogic opportunities as they might enable the teacher to provide support in the form of bridging the gap between the lab experiment and students' conceptual understanding.

\section{Concluding remarks}

The main aim was to provide knowledge about teacher support in a CSCL setting where students engaged with computer-supported collaborative lab work in science. The study 
showed how difficult it is for students to get a substantial understanding of the conceptual issues and procedures underlying a lab experiment even when supported by digital tools. From a sociocultural perspective, supporting students in their learning processes can be viewed in light of Vygotsky's (1978) concept of "the zone of proximal development," referring to what a learner can do with and without help from more experienced others. The current study showed that teacher support was pivotal for students' development of conceptual understanding, even when they also had peer collaboration and computer support. In general, the fact that students face conceptual challenges when working on complex scientific issues should not be seen as unambiguously negative. Student challenges have proven to be an excellent starting point for instruction (Linn and Eylon 2011). As displayed by the analyses of student-teacher interactions in the current study, digital support tools offer possibilities for creating shared spaces for peer and student-teacher dialogues in both group-based and whole-class settings.

As a concluding remark, several authors have emphasized the need for studies that address the role of the teacher in CSCL settings. Although the current study provides a contribution, further studies are needed, especially those that focus on different conceptual domains, digital resources and instructional designs. Such studies will improve our understanding of the complexity of students' conceptual sense-making and teacher support in naturalistic CSCL settings.

Acknowledgments I am grateful to Sten Ludvigsen, Andreas Lund and Palmyre Pierroux for their comments on earlier drafts. Special thanks are extended to Ingvill Rasmussen and Ingeborg Krange for their valuable contributions. I also want to thank the involved teachers and students in the SCY-Lab project. Thanks also to the anonymous reviewers for their valuable comments. The work was funded by the Department of Teacher Education and School Research and the former research centre InterMedia, University of Oslo. This study was conducted in the context of Science Created by You (SCY), which was funded by the European Community under the Information and Communication Technologies (ICT) theme of the 7th Framework Program for R\&D (grant agreement 212814). This document does not represent the opinions of the European Community, and the European Community is not responsible for any use that might be made of its content.

\section{Appendix}

Table 3 Transcript conventions

\begin{tabular}{ll}
$=$ & Break and subsequent continuation of a single utterance \\
(\# of seconds) & The time, in seconds, of a pause in speech \\
$()$. & A brief pause, usually less than $0.2 \mathrm{~s}$ \\
$\cdot$ & Falling pitch or intonation \\
? or up arrow & Rising pitch or intonation \\
!- & An abrupt halt or interruption in utterance \\
Underline & Emphasized or stressed speech \\
$(($ italic text $))$ & Annotation of non-verbal activity \\
\hline
\end{tabular}

Open Access This article is distributed under the terms of the Creative Commons Attribution 4.0 International License (http://creativecommons.org/licenses/by/4.0/), which permits unrestricted use, distribution, and reproduction in any medium, provided you give appropriate credit to the original author(s) and the source, provide a link to the Creative Commons license, and indicate if changes were made. 


\section{References}

Aleven, V., Stahl, E., Schworm, S., Fischer, F., \& Wallace, R. (2003). Help seeking and help design in interactive learning environments. Review of Educational Research, 73(3), 277-320.

Clarebout, G., \& Elen, J. (2006). Tool use in computer-based learning environments: towards a research framework. Computers in Human Behaviour, 22, 389-411.

Cole, M. (1996). Cultural psychology: A once and future discipline. Cambridge, MA: Belknap Press.

de Jong, T. (2006). Scaffolds for computer simulation based scientific discovery learning. In J. Elen, \& R. E. Clark (Eds.), Dealing with complexity in learning environments (pp. 107-128). London: Elsevier Science Publishers.

de Jong, T., Weinberger, A., Girault, I., Kluge, A., Lazonder, A. W., Pedaste, M., et al. (2012). Using scenarios to design complex technology-enhanced learning environments. Educational Technology Research \& Development, 60(5), 883-901.

de Jong, T., Linn, M. C., \& Zacharia, Z. C. (2013). Physical and virtual laboratories in science and engineering education. Science, 340, 305-308.

de Koning, B. B., Tabbers, H. K., Rikers, R. M., \& Paas, F. (2009). Towards a framework for attention cueing in instructional animations: guidelines for research and design. Educational Psychology Review, 21(2), 113-140.

Derry, S. J., Pea, R. D., Barron, B., Engle, R. A., Erickson, F., Goldman, R., et al. (2010). Conducting video research in the learning sciences: guidance on selection, analysis, technology, and ethics. The Journal of the Learning Sciences, 19, 3-53.

Dolonen, J. A., \& Ludvigsen, S. R. (2012). Analyzing students' interaction with a 3D geometry learning tool and their teacher. Learning, Culture and Social Interaction, 1(3-4), 167-182.

Furberg, A. (2009). Sociocultural aspects of prompting students' reflection in web-based learning environments. Journal of Computer Assisted Learning, 25, 397-409.

Furberg, A. L., \& Ludvigsen, S. (2008). Students' meaning making of socioscientific issues in computer mediated settings: exploring learning through interaction trajectories. International Journal of Science Education, 30(13), 1775-1799.

Furberg, A., Kluge, A., \& Ludvigsen, S. (2013). Student sensemaking with diagrams in a computer-based setting. International Journal of Computer-Supported Collaborative Learning, 8, 41-64.

Gillen, J., Littleton, K., Twiner, A., Staarman, J. K., \& Mercer, N. (2008). Using the interactive whiteboard to resource continuity and support multimodal teaching in a primary science classroom. Journal of Computer Assisted Learning, 24, 348-358.

Greiffenhagen, C. (2012). Making rounds: the routine work of the teacher during collaborative learning with computers. International Journal of Computer-Supported Collaborative Learning, 7(1), 11-42.

Hakkarainen, K., Lipponen, L., \& Järvelä, S. (2002). Epistemology of inquiry and computer-supported collaborative learning. In T. Koschmann, R. Hall, \& N. Miyake (Eds.), CSCL 2: Carrying forward the conversation (pp. 129-156). Mahwah, NJ: Lawrence Erlbaum Ass.

Hmelo-Silver, C. E. (2003). Analyzing collaborative knowledge construction: multiple methods for integrated understanding. Computers \& Education, 41, 397-420.

Hmelo-Silver, C. E., \& Barrows, H. S. (2008). Facilitating collaborative knowledge building. Cognition and Instruction, 26(1), 48-94.

Hofstein, A., \& Lunetta, V. N. (2003). The laboratory in science education: foundation for the 21 st century. Science Education, 88, 28-54.

Jaakkola, T., \& Nurmi, S. (2008). Fostering elementary school students' understanding of simple electricity by combining simulation and laboratory activities. Journal of Computer Assisted Learning, 24(4), 271-283.

Janssen, J., Erkens, G., \& Kanselaar, G. (2007). Visualization of agreement and discussion processes during computer-supported collaborative learning. Computers in Human Behavior, 23, 1105-1125.

Jefferson, G. (1984). Transcription notation. In J. Atkinson, \& J. Heritage (Eds.), Structures of social interaction (pp. ix-xvi). New York: Cambridge University Press.

Jordan, B., \& Henderson, K. (1995). Interaction analysis: foundations and practice. The Journal of the Learning Sciences, 4(1), 39-103.

Jornet, A., \& Roth, W.-M. (2015). The joint work of connecting multiple (re)presentations in science classrooms. Science Education, 99(2), 378-403.

Kershner, R., Mercer, N., Warwick, P., \& Kleine Staarman, J. (2010). Can the interactive whiteboard support young children's collaborative communication and thinking in classroom science activities? Computer Supported Collaborative Learning, 5, 359-383.

Kluge, A. (2014). Combining laboratory experiments with digital tools to do scientific inquiry. International Journal of Science Education, 36(13), 2157-2179.

Kozma, R. (2003). The material features of multiple representations and their cognitive and social affordances for science understanding. Learning and Instruction, 13, 205-226. 
Linell, P. (2009). Rethinking language, mind and world dialogically: Interactional and contextual theories of human sense-making. Charlotte, NC: Information Age Publishing, Inc..

Linn, M., \& Eylon, B.-S. (2011). Science learning and instruction. taking advantage of technology to promote knowledge integration. New York: Routledge.

Lunetta, V. N., Hofstein, A., \& Clough, M. (2007). Learning and teaching in the school science laboratory: An analysis of research, theory, and practice. In N. Lederman, \& S. Abel (Eds.), Handbook of research on science education (pp. 393-441). Mahwah, NJ: Lawrence Erlbaum.

Mäkitalo-Siegl, K., \& Fischer, F. (2011). Stretching the limits in help seeking research: theoretical, methodological, and technological advances. Learning and Instruction, 21(2), 243-246.

Mäkitalo-Siegl, K., Kohnle, C., \& Fischer, F. (2011). Computer-supported collaborative inquiry learning and classroom scripts: effects on help seeking processes and learning outcomes. Learning and Instruction, 21(2), 257-266.

Mercer, N. (2004). Sociocultural discourse analysis: analysing classroom talk as a social mode of thinking. Journal of Applied Linguistics, 1(2), 137-168.

Mercer, N. (2013). The social brain, language, and goal-directed collective thinking: A social conception of cognition and its implications for understanding how we think, teach, and learn. Educational Psychologist, 48(3), 148-168.

Mercer, N., \& Littleton, K. (2007). Dialogue and the development of children's thinking: A sociocultural approach. London: Routledge.

Olympiou, G., \& Zacharia, Z. C. (2011). Blending physical and virtual manipulatives: An effort to improve students' conceptual understanding through science laboratory experimentation. Science Education, 96(1), 21-47.

Puustinen, M., \& Rouet, J.-F. (2009). Learning with new technologies: help seeking and information searching revisited. Computers \& Education, 53(4), 1014-1019.

Quintana, C., Reiser, B. J., Davis, E. A., Krajcik, J., Fretz, E., Duncan, R. G., et al. (2004). A scaffolding design framework for software to support science inquiry. The Journal of the Learning Sciences, 13(3), 337-386.

Reid, D. J., Zhang, J., \& Chen, Q. (2003). Supporting scientific discovery learning in a simulation environment. Journal of Computer Assisted Learning, 19, 9-20.

Renken, M. D., \& Nunez, N. (2013). Computer simulations and clear observations do not guarantee conceptual understanding. Learning and Instruction, 23, 10-23.

Rutten, N., van Joolingen, W. R., \& van der Veen, J. T. (2012). The learning effects of computer simulations in science education. Computers \& Education, 58, 136-153.

Säljö, R. (2010). Digital tools and challenges to institutional traditions of learning: technologies, social memory and the performative nature of learning. Journal of Computer Assisted Learning, 26, 53-64.

Salmon, G. (2000). E-moderating. the key to teaching and learning online. London: Kogan Page.

Sandoval, W. A., \& Reiser, B. J. (2004). Explanation-driven inquiry: integrating conceptual and epistemic scaffolds for scientific inquiry. Science Education, 88, 345-372.

Scardamalia, M., \& Bereiter, C. (2006). Knowledge building: theory, pedagogy, and technology. In K. Sawyer (Ed.), Cambridge handbook of the learning sciences (pp. 97-118). New York, NY: Cambridge University Press.

Smetana, L. K., \& Bell, R. L. (2012). Computer simulations to support science instruction and learning: A critical review of the literature. International Journal of Science Education, 34(9), 1337-1370.

Stegmann, K., Weinberger, A., \& Fischer, F. (2007). Facilitating argumentative knowledge construction with computer-supported collaboration scripts. International Journal of Computer-Supported Collaborative Learning, 2(4), 421-447.

Strømme, T. A., \& Furberg, A. (2015). Exploring teacher intervention in the intersection of digital resources, peer collaboration, and instructional design. Science Education, 99(5), 837-862.

van Joolingen, W. R., de Jong, T., \& Dimitrakopoulout, A. (2007). Issues in computer supported inquiry learning in science. Journal of Computer Assisted Learning, 23, 111-119.

van Leeuwen, A., Janssen, J., Erkens, G., \& Brekelmans, M. (2013). Teacher interventions in a synchronous, colocated CSCL setting: analyzing focus, means, and temporality. Computers in Human Behavior, 29, 1377-1386.

Vygotsky, L. S. (1978). Mind in society: The development of higher social processes. Cambridge, MA: Harvard University Press.

Vygotsky, L. S. (1986). Thought and language. Cambridge: The MIT Press.

White, B. Y., \& Frederiksen, J. (1998). Inquiry, modeling, and metacognition: making science accessible to all students. Cognition and Instruction, 16, 3-118.

White, T., \& Pea, R. (2011). The emergence of abstract representations in dyad problem solving. The Journal of the Learning Sciences, 20(3), 489-547.

Zhang, J., Chen, Q., Sun, Y., \& Reid, D. J. (2004). Triple scheme of learning support design for scientific discovery learning based on computer simulation: experimental research. Journal of Computer Assisted Learning, 20, 269-292. 